\title{
シンポジウム 123
}

\section{内科学の新たな視点における病態の理解 〜epigeneticsから臓器連関まで〜}

\section{4）肥満症の新たな視点一細胞内ストレス 応答系を活用した治療法開発}

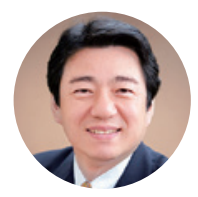

荒木 栄一 1) 近藤 龍也 ${ }^{1)}$ 甲斐 広文 ${ }^{2)}$

Key wordsメタボリックシンドローム，糖尿病，ヒートショック蛋白，インスリン抵抗性，慢性炎症

\section{はじめに}

肥満症とは，肥満に起因ないしは関連する健 康障害を合併し，医学的に減量を必要とする病 態をいい, 疾患として取り扱う必要がある。肥 満状態では，脂肪細胞や脂肪組織に浸潤したマ クロファージ由来の液性因子や活性酸素種など を介し，酸化ストレスや小胞体ストレス，炎症 性シグナルなどが誘導され, 慢性の炎症やイン スリン抵抗性を惹起し, メタボリックシンド ロームや糖尿病, さらには動脈硬化症などの発 症・進展に関与する。一方, 生体には, 小胞体 ストレス応答経路や熱ショック応答(heat shock response : HSR) 経路など, これらのストレス から細胞や組織を防御する仕組みが備わってい
る。熱などのストレスを介したHSR経路によっ て誘導される代表的な分子シャペロンheat shock protein (HSP) 72 は, 蛋白質の高次構造 や超分子構造の形成や修復を担う。 また, 炎症 性シグナルを伝達するc-Jun N-terminal kinase (JNK) やapoptosis signal-regulating kinase 1(ASK1) と直接結合し，これらの活性を抑制する(図1). 本稿では, HSR経路の活性化を介して, 肥満に よるメタボリックシンドロームや糖尿病を治療 しようとする試みを紹介する。

1. 肥満とメタボリックシンドローム, 2 型糖尿病の関連

肥満症の発症には, 特に内藏脂肪の蓄積が大

1)熊本大学大学院生命科学研究部代謝内科学分野, 2) 同 生命科学研究部遺伝子機能応用学分野

$113^{\text {th }}$ Scientific Meeting of the Japanese Society of Internal Medicine : Symposium : 3. Insight into the mechanism of diseases on new perspective arising in internal medicine : from epigenetics to organ associations ; 4) Novel insight into obesity disease-Development of treatment employing the modulation of intracellular stress response pathways.

Eiichi Araki $^{1)}$, Tatsuya Kondo ${ }^{1)}$ and Hirofumi Kai ${ }^{2)}:{ }^{11}$ Department of Metabolic Medicine, Faculty of Life Sciences, Graduate School of Medical Sciences, Kumamoto University, Japan and ${ }^{2}$ Department of Molecular Medicine, Faculty of Life Sciences, Graduate School of Pharmaceutical Sciences, Kumamoto University, Japan.

本講演は，平成28年4月17日（日）東京都・東京国際フォーラムにて行われた. 


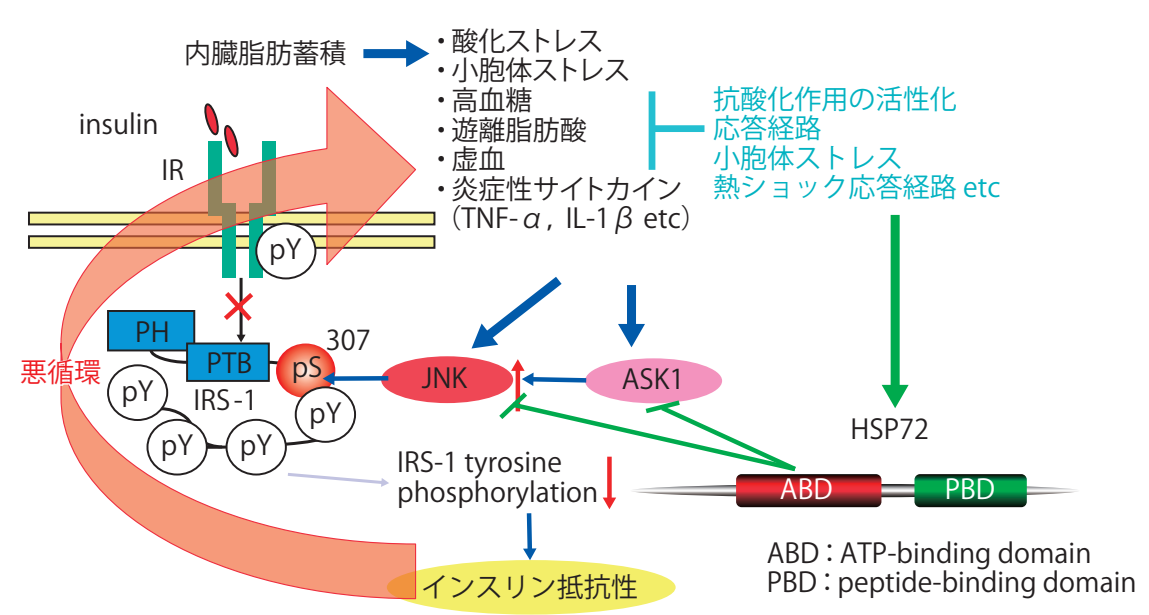

図1 内臓脂肪蓄積による生体内ストレス増加と生体におけるストレス応答経路 内臓脂肪の蓄積は，酸化ストレスや遊離脂肪酸の増加，アディポカインの産生異常， TNF- $a$ などの炎症性サイトカイン分泌の増加などをもたらす。その結果, ASK1やJNK を代表とするストレスキナーゼが活性化される。活性化されたJNKはIRS-1のセリン残 基のリン酸化を促進し，インスリンによるIRS-1のチロシンリン酸化が抑制され，イン スリン抵抗性が惹起される。インスリン抵抗性はさらに慢性のストレス，炎症状態を 増悪させ，肥満症が促進される. 一方，生体には，小胞体ストレス応答経路や熱ショ ック応答 (HSR) 経路など，ストレスから細胞や組織を防御する仕組みが備わってい る. HSR経路によって誘導されるHSP72は，タンパク質の高次構造や超分子構造の形 成や修復を担う. またJNKやASK1 と直接結合し，これらの活性を抑制する.

きな役割を果たすと考えられている．脂肪細胞 から供給される遊離脂肪酸や種々のアディポカ イン, あるいは脂肪組織に浸潤したマクロ ファージから分泌されるTNF (tumor necrosis factor)- $\alpha$゙どの炎症性サイトカインは生体機能 に影響を及ぼす。内臓脂肪の蓄積は, 遊離脂肪 酸の肝藏への供給増加, アディポカインの産生 異常, TNF- $\alpha$ な゙の炎症性サイトカイン分泌の 増加などをもたらし，また，脂肪組織における 酸化ストレスの増加や後述するインスリン抵抗 性の増悪を介した血糖や血圧の上昇を惹起し, さらに慢性のストレス, 炎症状態を増悪させ る.このようにして, メタボリックシンドロー ムや脂質異常症, 2 型糖尿病, 高血圧あるいは 動脈硬化症などの発症が促進される ${ }^{1)}$.

$$
\text { インスリン作用は, インスリンがインスリン }
$$

受容体（insulin receptor：IR）と結合し，その $\beta$ サブユニットに存在するチロシンキナーゼを活
性化することによって伝達される。活性化され たチロシンキナーゼは, insulin receptor substrate (IRS)-1などの細胞内基質のチロシン残基 のリン酸化を促し，このチロシン残基にシグナ ル伝達蛋白が結合して下流へとシグナルが伝達 されていく.内臓脂肪の蓄積は, TNF- $\alpha$ どの 炎症性のサイトカイン分泌を促進させ, その結 果, ASK1 やJNKを代表とするストレスキナーゼ が活性化される. 活性化されたJNKはIRS-1のセ リン残基のリン酸化を促進し，このことによっ てインスリンによるIRS-1 のチロシンリン酸化 が抑制され，インスリン作用の減弱，すなわち インスリン抵抗性が惹起される2) (図1).このよ うなインスリン抵抗性は, 上記のごとく悪循環 をもたらし, 肥満による様々な疾患の発症を促す。 


\section{2. 熱ショック応答(HSR)経路活性化の機序}

ストレス応答経路の中でも, HSR経路は古く から知られており, 単細胞生物から脊椎動物ま で保存されている，重要な生体防御機構であ る. 生体が過剩な熱にさらされると, 蛋白の変 性が起こり，細胞障害が惹起される。このよう な熱などのストレスにより誘導され，蛋白の変 性を修復し，細胞機能を維持する働きをもつ分 子シャペロンとして同定されたのがHSPである.

実際には, 熱以外にも様々な因子によって HSPの発現誘導が惹起されることが知られてい る。代表的なHSPであるHSP72の発現は，この ような熱などのストレスによって転写因子heat shock factor (HSF)-1が活性化され, 三量体と なったHSF-1 がHSP72遺伝子に存在する特異的 配列HSE（heat shock element）に結合して転写 レベルで誘導される.HSP72には，シャペロン としての活性を持つATP結合部位（ATP-binding domain）と，折りたたみの悪い蛋白を認識して 結合する peptide-binding domainが存在し, 蛋白 質の高次構造や超分子構造の形成や修復に関与 する，また，JNKやその上流のASK 1 と直接結合 し，これらの活性化を抑制することが知られて いる ${ }^{3,4)}$.

\section{3. 温熱と微弱電流の同時印可による HSP72 の誘導}

1999年, Hooperらは 1 週間に6日, 1 回30分 の温水浴を 3 週間継続後に, 白人 2 型糖尿病患 者の血糖コントロールが改善することを報告し た ${ }^{5)}$ 。また, 1 回 15 分 $60^{\circ} \mathrm{C}$ のサウナを 2 週間継 続すると，2型糖尿病患者の空腹時血糖值が改 善することも報告されている6). このような温 熱による血糖改善効果の一部は, HSR経路を介 している可能性がある.

著者らは, 温熱と直流のパルス状微弱電流の 組み合わせによって, 効率的に細胞や生体内に
HSP72を誘導する方法を開発し, in vitro, in vivo においてその作用を解析した ${ }^{7 \sim 10)}$.

In vitroの系において, 温熱と特定のパルス幅 で特定周期の直流電流の組み合わせ（mild electrical stimulation and thermo: MET療法) がHSP72 蛋白を強く誘導すること, HSP72蛋白の誘導が インスリンによるAktの活性化を増強すること を見出した ${ }^{7 \sim 9)}$. また, 高脂肪食を負荷した肥 満 2 型糖尿病モデルマウスにおいて, MET療法 が脂肪細胞を小型化し，内臓脂肪を減少させ， 肝臓におけるインスリンシグナルを改善, 而糖 能を改善することを確認した ${ }^{10)}$ (図2)。さらに, 肥満と膵 $\beta$ 細胞障害による糖尿病モデルである $\mathrm{db} / \mathrm{db}$ マウスにおいてMET療法は耐糖能の改善 とともに，膵島におけるHSP72蛋白を誘導し， 膵 $\beta$ 細胞のインスリン含量を増加させ， $\beta$ 細胞機 能の維持に重要な転写因子PDX-1の核局在を増 加させ，アポトーシスシグナルを伝達する cleaved-caspase-3の発現を抑制するなど, 膵 $\beta$ 細 胞の障害を減少させた ${ }^{11)}$.

興味深いことに, HSP72を誘導することが知 られている薬剤GGA (geranylgeranylacetone) を 高脂肪食による肥満糖尿病モデルマウスに経口 投与すると, 肝臓においてHSP72蛋白の誘導が 起こり, 肝臓のJNKの活性化抑制と糖新生系酵 素発現の抑制を認め, 空腹時の血糖值とインス リン值が有意に抑制された ${ }^{12)}$ 。このように， MET療法以外のHSP72誘導法によっても耐糖能 改善効果が確認された。

\section{MET療法の臨床応用}

まずMET療法の安全性を確認するために, 10 名の健常人男性において週 2 回, 連続 8 週間の MET療法（温度 $42^{\circ} \mathrm{C}$, 電圧 $1.4 \pm 0.1 \mathrm{~V} / \mathrm{cm}$, パ ルス幅 $0.1 \mathrm{msec}, 55 \mathrm{pulse} / \mathrm{sec}, 30$ 分）を施行 した。 その結果, MET療法は特別な有害事象を 示さず, TNF- $\alpha や C$-reactive protein (CRP) といっ た血中の炎症マーカーを有意に減少させた ${ }^{13)}$. 


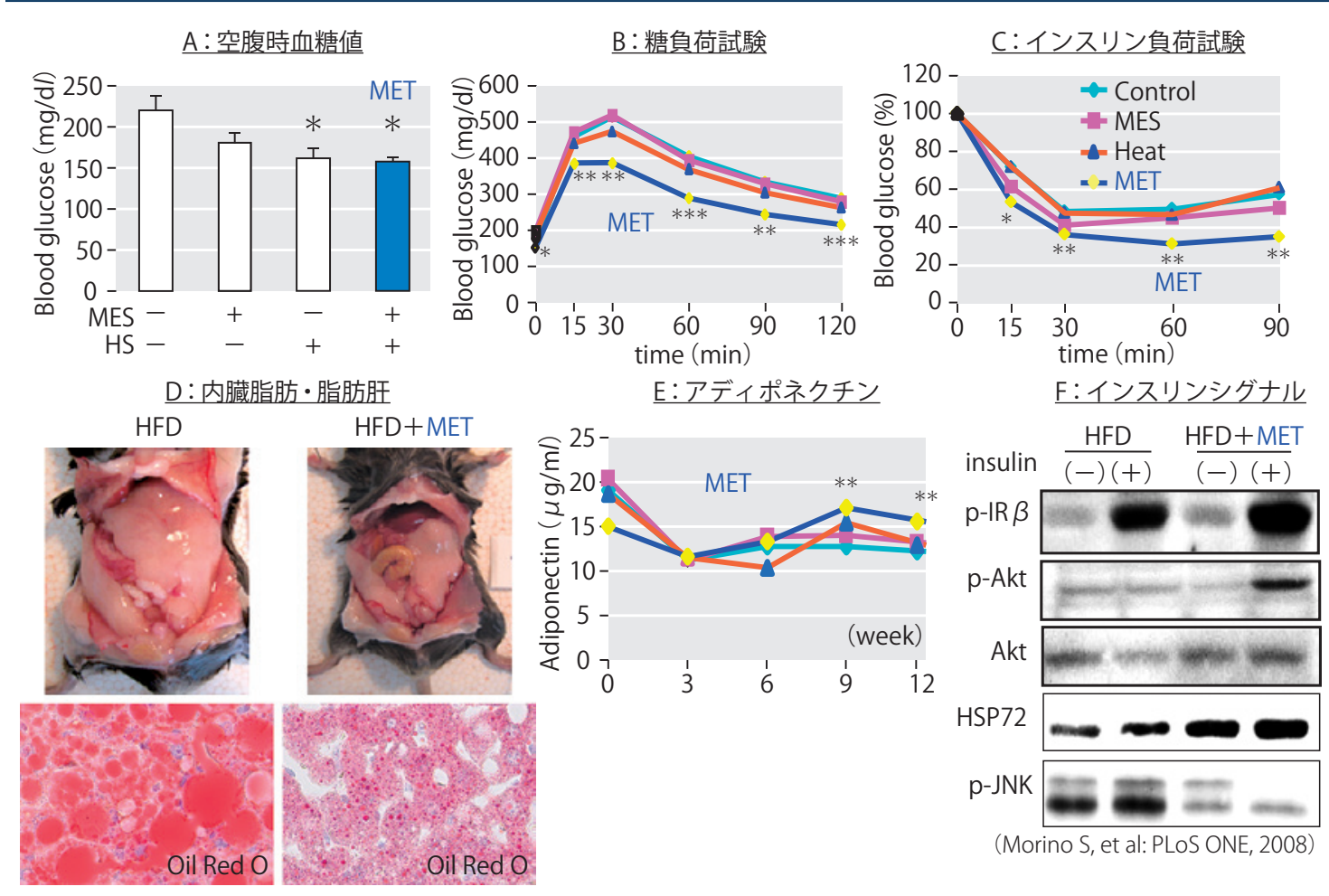

図2 温熱と微弱電流同時印加（MET）療法の高脂肪食負荷糖尿病モデルマウスにおける効果

高脂肪食負荷糖尿病モデルマウスにMET療法を施行すると，空腹時血糖值の改善 (A) と糖負荷試験時の血糖値 の低下 (B)，およびインスリン抵抗性の改善 (C) を認める.ささらに，内臓脂肪の減少と肝臓における中性脂肪 蓄積の抑制 (D)，血中アディポネクチン低下の抑制 (E)，および肝㵴におけるHSP72蛋白の誘導とリン酸化JNK の減少，ならびにインスリン刺激後のインスリン受容体チロシンリン酸化と下流のAkt活性化を認める (F).

糖尿病モデルマウスで認められた内臓脂肪の減 少効果を，腹部CT検査を用いて検証すると， MET治療期間中の減少傾向は認めたものの, 有 意な減少ではなかった。

次に, メタボリックシンドローム該当の日本 人男性 40 名において, MET療法の効果を調べ た. 対象者を 2 群に分け, 第 1 群は最初の 12 週 間, 週 4 回のMET療法（温度 $42^{\circ} \mathrm{C}$, 電圧 $1.4 \pm$ $0.1 \mathrm{~V} / \mathrm{cm}$, パルス幅 $0.1 \mathrm{msec}, 55 \mathrm{pulse} / \mathrm{sec}, 60$ 分）にて治療を行い, 残りの 12 週間はMET療法 なしで生活習慣などを変えないように指導して 観察した。第 2 群は, 第 1 群と逆の順番で介入 する, クロスオーバーの介入を行った. 治療前, 前半 12 週間の介入後, および後半 12 週間の介 入後に採血や経口ブドウ糖負荷試験, 腹部CT検
査による脂肪面積の計測を行った.

その結果, MET療法は内臓脂肪面積の有意な 減少, 収縮期/拡張期血圧の低下, 空腹時の血糖 值とインスリン值およびインスリン抵抗性の指 標であるHOMA-IR (homeostasis model assessment of insulin resistance) の低下, TNF- $\alpha$ やCRP, 白血球数などの血中炎症マーカーの減少をもた らした。一方，メタボリックシンドローム該当 者では, 介入前のHbA1c值が低いためか, 有意 なHbA1c低下は認めなかった ${ }^{14)}$.

さらに, 肥満を有する(BMI (body mass index) 25）の日本人 2 型糖尿病男性患者 40 名におい て, メタボリックシンドローム該当者と同じプ ロトコールでMET療法による介入を行った。 肥 満の 2 型糖尿病患者では，これらのメタボリッ 


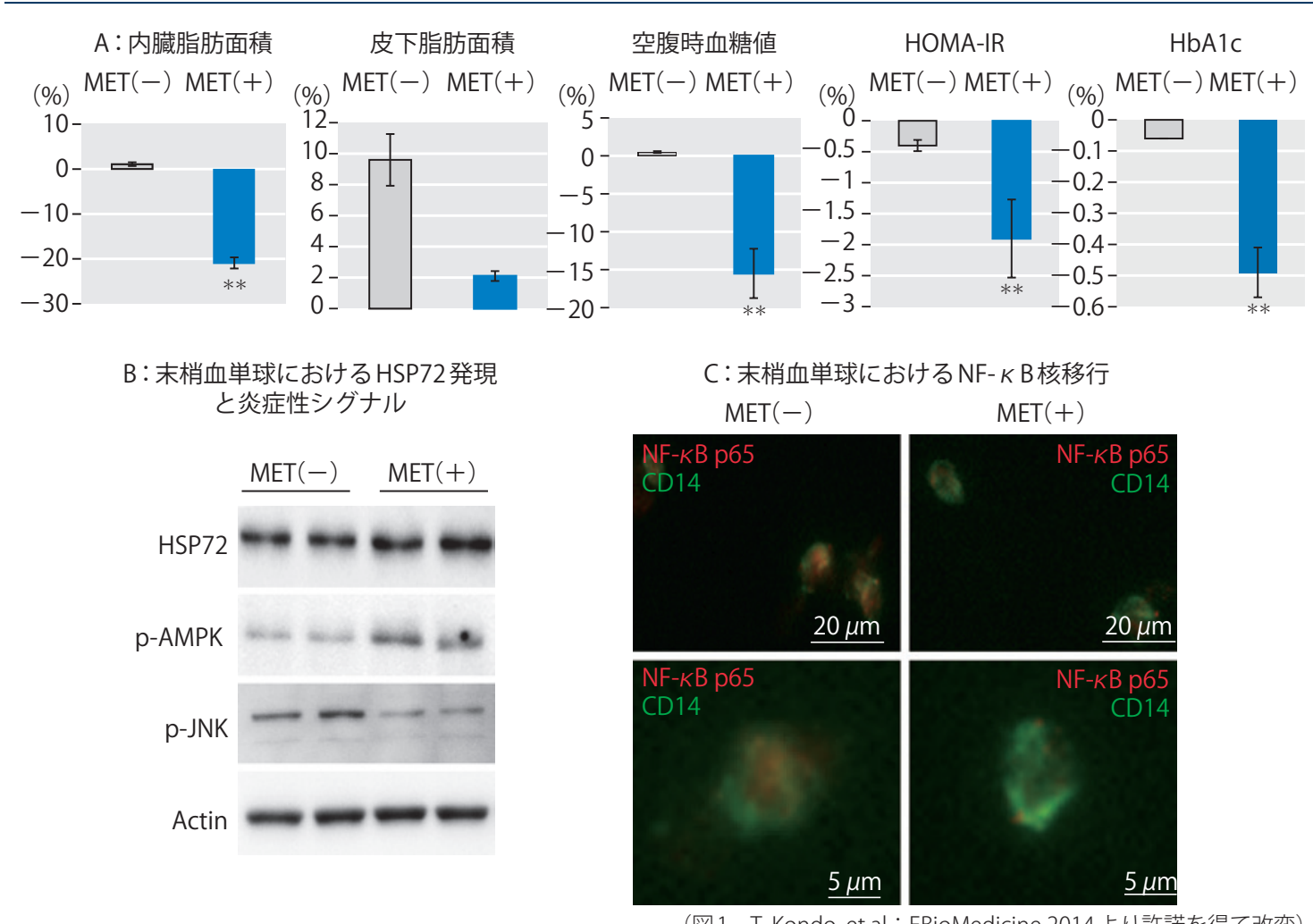

図3 温熱と微弱電流同時印加（MET）療法のヒト肥満2型糖尿病患者への介入試験

肥満男性 2型糖尿病患者 40名におけるMET療法の効果を示す．MET療法によって，内臓脂肪面積，空腹時血糖 值，HOMA-IR，HbA1cの有意な減少を認めた（A).MET療法によって末梢血単球のHSP72発現が亢進し，JNK 活性が抑制され (B)，単球におけるNF- $K$ Bの核移行が抑制された (C).

表＼cjkstart温熱と微弱電流同時印加（MET）療法の糖尿病モデルマウスおよび健常男性， メタボリックシンドローム (metabolic syndrome：MS) 該当男性, 肥満2型糖尿病患者への効果（まとめ）

\begin{tabular}{|c|c|c|c|c|c|}
\hline 方法 & MET & GGA & MET & MET & MET \\
\hline 対象 & 糖尿病モ & ルマウス & 健常男性 & MS 男性 & 2 型糖尿病 \\
\hline • 体重 & $\rightarrow$ & $\downarrow$ & $\rightarrow$ & $\rightarrow$ & $\rightarrow$ \\
\hline • 内臓脂肪 & $\downarrow$ & $\downarrow$ & $\rightarrow$ & $\downarrow$ & $\downarrow$ \\
\hline ・インスリン抵抗性 & $\downarrow$ & $\downarrow$ & $\rightarrow$ & $\checkmark$ & $\nabla$ \\
\hline •JNK活性 & †(肝臓) & †(肝臟) & N.D. & N.D. & V(末梢血単球) \\
\hline • 炎症性サイトカイン & $\downarrow$ & $\downarrow$ & $\downarrow$ & $\downarrow$ & $\checkmark$ \\
\hline • $\beta$ 細胞傷害 & $\downarrow$ & N.D. & $\rightarrow$ & $?$ & $?$ \\
\hline ・血糖値 & $\downarrow$ & $\downarrow$ & $\rightarrow$ & $\forall$ & $\downarrow$ \\
\hline - $\mathrm{HbA1c}$ & N.D. & N.D. & N.D. & $\rightarrow$ & 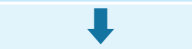 \\
\hline
\end{tabular}

MET : mild electric stimulation and thermo, GGA : geranylgeranylacetone, N.D. : not done 
クシンドローム該当者において認められた内蔵 脂肪減少効果, 血圧低下, 空腹時の血糖值とイ ンスリン值およびHOMA-IRの低下, TNF- $\alpha や$ $\mathrm{CRP}$, 白血球数などの血中炎症マーカーの減少 に加えて, 有意なHbA1cの低下をもたらした。 MET療法を行った患者の未梢血の単核球を単離 して解析すると, MET療法前と比較してHSP72 蛋白の発現増加とJNK活性の抑制, CRPやTNF- $\alpha$ mRNAの抑制が認められ, また炎症シグナルを 伝達する転写因子NF- $\kappa$ Bの核移行も抑制されて おり, 生体内でのストレス抑制効果が示唆され た (図3 ${ }^{14)}$.

\section{おわりに}

糖尿病モデル動物を用いた解析やヒト末梢血 単球を用いた研究から, MET療法のインスリン 抵抗性や而糖能改善効果, 慢性炎症の抑制効果 の少なくとも一部はHSP72の発現誘導を介して
いると考えられた(表). 糖尿病患者では, HSP72 蛋白の発現が低下しているとの報告もなされて おり ${ }^{15,16)}$, HSP72蛋白の発現を誘導するような 方法は, 糖尿病や慢性炎症を介して生じる様々 な疾患の発症予防や病態進展阻止に有意義であ ると考えられる.

一方, MET療法の効果の一部が, HSP72誘導 以外の経路を介していることも十分に想定され る. 他のHSPの関与, 自律神経系を介した経路, あるいは熱などの物理的刺激を伝達することが 知られているtransient receptor potential (TRP) channelを介した経路などがその候補として挙 げられよう17)。詳細な機序の解明が, 新たな生 活習慣病の新規治療法開発につながることを期 待したい.

著者のCOI（conflicts of interest）開示: 本論文発表内容 に関連して特に申告なし 
1) Romeo GR, et al : Metabolic syndrome, insulin resistance, and roles of inflammation-mechanisms and therapeutic targets. Arterioscler Thromb Vasc Biol 32 : 1771-1776, 2012.

2) Hirosumi J, et al : A central role for JNK in obesity and insulin resistance. Nature 420 : 333-336, 2002.

3) Morimoto RI, et al : The heat-shock response : regulation and function of heat-shock proteins and molecular chaperones. Essays Biochem 32 : 17-29, 1997.

4) Morimoto RI : Cells in stress : Transcriptional activation of heat shock genes. Science 259 : 1409-1410, 1993.

5) Hooper PL : Hot-tub therapy for type 2 diabetes mellitus. N Engl J Med 341 : 924-925, 1999.

6) Biro S, et al : Clinical implications of thermal therapy in lifestyle-related diseases. Exp Biol Med(Maywood) 228 : 1245-1249, 2003.

7) Yano S, et al: Glucose uptake in rat skeletal muscle L6 cells is increased by low-intensity electrical current through the activation of the phosphatidylinositol-3-OH kinase (PI-3K)/Akt pathway. J Pharmacol Sci 115 : 9498, 2011.

8) Morino-Koga $\mathrm{S}$, et al : Insulin receptor activation through its accumulation in lipid rafts by mild electrical stress. J Cell Physiol 228 : 439-446, 2013.

9) Morino S, et al : Mild electrical stimulation increases ubiquitinated proteins and Hsp72 in A549 cells via attenuation of proteasomal degradation. J Pharmacol Sci 108 : 222-226, 2008.

10) Morino, S, et al : Mild electrical stimulation with heat shock ameliorates insulin resistance via enhanced insulin signaling. PLoS One 3 : e4068, 2008.

11) Kondo, $\mathrm{T}$, et al : Hyperthermia with mild electrical stimulation protects pancreatic beta-cells from cell stresses and apoptosis. Diabetes $61: 838-847,2012$.

12) Adachi $\mathrm{H}$, et al : An acylic polyisoprenoid derivative, geranylgeranylacetone protects against visceral adiposity and insulin resistance in high fat fed mice. Am J Physiol Endocrinol Metab 299 : E764-771, 2010.

13) Kondo, $\mathrm{T}$, et al : Heat shock treatment with mild electrical stimulation safely reduced inflammatory markers in healthy male subjects. Obes Res Clin Pract 4 : e83-162, 2010.

14) Kondo T, et al : Mild Electrical Stimulation with Heat Shock Reduces Visceral Adiposity and Improves Metabolic Abnormalities in Subjects with Metabolic Syndrome or Type 2 Diabetes : Randomized Crossover Trials. EBioMedicine $1: 80-89,2014$.

15) Kurucz I, et al : Decreased expression of heat shock protein 72 in skeletal muscle of patients with type 2 diabetes correlates with insulin resistance. Diabetes 51 : 1102-1109, 2002.

16) Hooper, PL, et al : The importance of the cellular stress response in the pathogenesis and treatment of type 2 diabetes. Cell Stress Chaperones $19: 447-464,2014$

17) Moran MM, et al : Transient receptor potential channels as therapeutic targets. Nat Rev Drug Discov 10 : $601-$ $620,2011$. 